\title{
Editorial: Cardiff Bay Barrage and Cardiff Bay
}

\section{B. Davies}

The decision of the Institution of Civil Engineers to publish these technical papers in this special edition of Water and Maritime Engineering is timely. The papers were originally presented at a one-day technical symposium on the Cardiff Bay Barrage and the regeneration of Cardiff Bay held at the St David's Hotel in Cardiff in February 2000.

That symposium marked the end of the construction phase of the Barrage and the transfer of the responsibility for its management and operation to Cardiff County Council on 1 April 2001. That historic date marked the substantial completion of the Barrage as a key feature in the regeneration of Cardiff Bay and the establishment of the Cardiff Harbour Authority as the vehicle for managing the transition from the Barrage as a construction project to a key asset in the attractions available in Cardiff Bay for regeneration and tourism potential.

The papers cover the background to the construction scheme from its inception to completion, and detail the technical and environmental challenges that had to be met to complete this regeneration project. It is important that the story of the Cardiff Bay Barrage and the civil engineering design, construction and project management feat that accomplished the creation of the impounded lake is acknowledged and recorded in professional publications such as this. The construction of the Barrage stands as a great engineering achievement, and will contribute greatly to the regeneration of Cardiff in the coming decades.

As expected on a project of this nature, concerns were raised about the potential consequences for flooding, groundwater, water use, fish migration and bird habitats. These concerns were addressed by good design, project planning and effective public consultation, and the task now facing the Harbour Authority is to ensure that the communities that have been so accommodating of the construction phase will benefit along with the people of Cardiff and indeed Wales from a barrage project that will be the catalyst for economic, environmental and social regeneration over the next decade.

Cardiff County Council in October 1999 agreed to the request from the First Minister of the National Assembly for Wales to take on the operational and management role of the Harbour Authority. The lead-in period to the transfer on 1 April 2000 was therefore a very short period during which arrangements were effectively put in place to successfully assume full responsibility. The smooth transition was a feat in itself, and is a tribute to the joint working between the National Assembly for Wales and the Council, and in particular the staff that undertook the detailed preparatory work and the take-up of responsibilities. This was a demonstration of the capability of the public sector to act in a businesslike and decisive way. The whole process was achieved against a background of media doubts that such a transition could be successfully accomplished, and it has been to the credit of all the staff concerned that they have proved such doubts to have been completely unfounded.

After the transition there remained a great deal of work to be done so that the full potential of the Barrage and Cardiff Bay could be realised. Much work remained to be completed, and the health and safety aspects of a tourist attraction needed to be addressed. The sophisticated computer control systems needed to be fully operational and the training and maintenance requirements established. The dredging of the Bay needed to be progressed against tight timescales; the provision of an aeration system and the landscaping of the Barrage were three major elements that had to be carried out.

The dredging scheme proposed for the Bay was appraised and totally reviewed as a matter of priority, and a scheme to remove $620000 \mathrm{~m}^{3}$ was completed within the timescale and the difficult environmental constraints required of a project of this nature. The options for aerating the Bay were also appraised and reviewed, and an innovative aeration system developed within Wales was procured and installed following a competitive tendering process. The chosen solutions have proved to be successful in maintaining water quality, and allow a degree of flexibility to deal with environmental changes. There has been a bottom-line cost saving of over $£ 2$ million against an original option to use a 'bubbler boat'. The landscaping scheme for the Barrage was also reappraised and redesigned and now provides a longitudinal park along the water edge that is attractive both to visitors and to local residents.

Much has already been achieved, but the Harbour Authority is continuing to work on the completion of the development of the Bay area and-most importantly-in improving communication with key stakeholders to achieve the aim of regeneration of the Cardiff Bay area. Major developments proposed for this area include the International Sports Village at the Ferry Road Peninsula, which will create a destination point that will 
be a true European experience for a range of sporting events, and a combination of residential and high technology offices. There are plans to develop high-tech business units and infrastructure alongside the operational port in the Bay area, and the public transport systems are being planned for an area that is likely to take off, in both regeneration and tourism terms, over the next decade. The links with the city centre through road, rail and water-based transportation systems will complement the renaissance of the Bay area, and attention is being given to ensuring that pedestrian, cycle and disabled access will be available wherever practical.
The Bay is proving an attractive area both for boat owners and for investors, with a current $20 \%$ increase in boat use year on year. The Barrage has already become a visitor attraction in its own right, with the number of visitors expected to reach 400000 in this, the first year of opening. I am confident that, with the progress that is being made in completing the developments, improved access and the attraction of events, both on the water and around the Bay edge, the Barrage's potential to act as a catalyst for development and an attractive tourist resource for the wider region will be fully realised and acknowledged. 